\title{
PENILAIAN KEPUASAN PELANGGAN TERHADAP KUALITAS LAYANAN X DENGAN METODE SERVQUAL DAN ANALYTICAL HIERARCHY PROCESS
}

\author{
Amanda Eka Ratna Putri ${ }^{1}$, Wahyudi Harianto ${ }^{2}$, Abdul Aziz ${ }^{3}$ \\ Prodi Teknik Informatika, Universitas Kanj'uruhan Malang ${ }^{1,2,3}$ \\ amandaratna065@gamil.com¹,wahyudi@unikama.ac.id², abdul.aziz@unikama.ac.id ${ }^{3}$
}

\begin{abstract}
Abstrak. Penelitian ini bertujuan untuk mengetahui tingkat kepuasan pelanggan terhadap kualitas layanan serta memberikan urutan usulan perbaikan kualitas layanan $\mathrm{X}$ untuk memenuhi kualitas layanan X. Metode yang digunakan pada penelitian ini yaitu servqual (service quality) dan analytical hierarchy process (AHP). Dari hasil penelitian ini diketahui tingkat kepuasan pelanggan terhadap kualitas layanan $\mathrm{X}$ sudah puas dimata pelanggan dilihat dari nilai kepuasan pelanggan sebesar 4,025 artinya pelanggan sudah puas dengan pelayanan saat ini. Namun, masih terdapat kesenjangan sebesar -0,046. Atribut yang diusulkan untuk prioritas perbaikan yaitu terdapat pada atribut X2.1, X1.1, X4.3, X3.2, X3.1, X5.3 dan X5.2. Berdasarkan penilaian, 7 atribut tersebut memiliki nilai servqual terbobot lebih kecil dari nilai rata - rata servqual terbobot yaitu $-0,0054$.
\end{abstract}

Kata Kunci: Kepuasan Pelanggan, Servqual (Service Quality); AHP (Analytical Hierarchy Process).

\section{PENDAHULUAN}

Perusahaan tentu saja akan dihadapkan dengan sebuah persaingan. Persaingan saat ini terjadi bukan hanya dibidang kuliner atau produk saja, melainkan di bidang pelayanan jasa saat ini juga terjadi persaingan di seluruh dunia. Perusahaan yang bekerja di bidang produk dan jasa harus memiliki kualitas jasa yang baik bagi pelanggan, karena kualitas jasa dan produk sebuah perusahaan dapat berpengaruh pada kepuasan pelanggan. Metode servqual dapat digunakan untuk mengetahui kualitas pelayanan, dimana dimensi pada metode servqual ada 5 yaitu tangible, reliability, responsiveness, assurance, emphaty.

Untuk mengetahui tingkat kepuasan pelanggan dengan menggunakan kuisioner dan untuk mengetahui kualitas layanan atau kesenjangan antara harapan dan persepsi pelanggan digunakan metode servqual pada Gap 5 (Lissa, 2016). Selisih antara harapan dan persepsi pelanggan mengakibatkan kesenjangan yang dapat berdampak pada kepuasan pelanggan, dimana kepuasan pelanggan sangat penting bagi sebuah perusahaan, untuk memberikan atribut - atribut atau variabel pelayanan prioritas yang terdapat pada dimensi servqual yaitu dengan metode AHP (Ladyana, 2016). Untuk peningkatan kualitas pelayanan terhadap kepuasan pelanggan yaitu dengan menggunakan metode servqual (Heru \& Tb. Absor, 2018).

Kepuasan pelanggan merupakan bentuk respon pelanggan terhadap ketidaksesuaian terhadap kinerja yang dirasakan setelah penggunaan dengan harapan sebelumnya (Freddy, Riset Pemasaran, 2006)

Pada metode servqual digunakan untuk mengetahui kesenjangan atau gap terhadap kualitas layanan, kesenjangan atau gap yang dimaksud yaitu bagaimana harapan pelanggan dan persepsi terhadap pelayanan yang diberikan oleh pihak perusahaan (Wijaya \& Tony, 2011) Untuk menentukan nilai servqual dengan menggunakan rumus persamaan dibawah ini.

$$
\text { Skor SERVQUAL = skor persepsi }- \text { skor harapan }
$$


Dengan menganalisis skor servqual atau gap, perusahaan bisa mengidentifikasi dimensi dimensi pada metode servqual untuk penyempurnaan kualitas layanan.

Metode AHP diterapkan untuk mengambil keputusan dalam menyelesaikan masalah pada penyusunan prioritas. Untuk menyusun prioritas pada metode AHP dengan membuat sebuah kerangka pengambilan keputusan yang efektif pada persoalan lalu menyederhanakan dan mempermudah proses pengambilan keputusan dalam suatu susunan hirarki. Dengan mengetahui urutan bobot dari yang terbesar hingga terkecil maka dapat diketahui atribut mana yang dapat diprioritaskan.

\section{METODE PENELITIAN}

Populasi dan Sampel

Populasi adalah pelanggan pengguna jasa layanan X di PT. XYZ yang berjumlah 4147 pelanggan. Peneliti tidak mungkin mengambil sampel dari semua pelanggan. Jadi, peneliti menggunakan teknik pengambilan sampel yaitu menggunakan rumus slovin dengan batas tolerasi kesalahan 5\%. Hasil perhitungan yang sudah dilakukan mendapatkan angka 365 sampel.

\section{Pengumpulan Data}

Wawancara dilakukan dengan langsung bertemu kepada pihak manajemen PT. XYZ yang paham mengenai layanan $X$ untuk menilai kepentingan pada matriks perbandingan AHP. Kuisioner digunakan untuk memperoleh 2 data, yaitu data harapan dan data persepsi pelanggan layanan X. Kuisioner dan penilaian ini menggunakan kuisioner skala likert.

\section{Pengujian Data Kuisioner}

Uji Validitas digunakan dengan menganalisa item dari nilai pada setiap pertanyaan yang dikorelasikan dengan nilai total keseluruhan pertanyaan. Kuisioner dikatakan valid apabila nilai $\mathrm{r}_{\text {hitung }}$ lebih besar dari nilai $\mathrm{r}_{\text {tabel }}\left(\mathrm{r}_{\text {hitung }}>\mathrm{r}_{\text {tabel }}\right)$.

Uji Reliabilitas dilakukan agar mengetahui apakah hasil kuisioner dapat diandalkan berulang - ulang. Hasil pengujian reliabilitas akan dilihat berdasarkan pengelompokkan reliabilitas (Sugiyono, 2010).

\section{Pengolahan Data Kuisioner}

Pada metode servqual dilakukan analisa nilai pada gap 5 untuk mengetahui gap antara harapan pelanggan dan persepsi pelanggan, yang terdapat pada 5 dimensi servqual. Untuk menghasilkan nilai kesenjangan yaitu dengan menghitung nilai selisih antara nilai harapan dan nilai persepsi pelanggan.

Informasi nilai rata - rata harapan dan persepsi pelanggan dapat digambarkan dalam sebuah diagram kartesius untuk menghubungkan antara harapan dan persepsi pelanggan yang dibagi menjadi 4 kuadran.

Pada metode AHP dilakukan pembobotan pada kriteria kualitas layanan yang terdapat pada 5 dimensi servqual dan juga dilakukan pada butir - butir pernyataan pada kriteria (sub kriteria).

\section{HASIL DAN PEMBAHASAN}

Karakteristik responden

Gambaran karakteristik umum pada penelitian ini meliputi usia, pekerjaan, dan lama berlangganan. Dari 365 responden pada karakteristik responden yang berusia $\leq 15$ tahun mendapat prosentase sebesar $2 \%$ yaitu sebanyak 9 orang. Lalu $19 \%$ berusia $16-20$ tahun yaitu 69 orang. Kemudian dengan prosentase $40 \%$ berusia $21-26$ tahun dengan jumlah 146 orang. Untuk prosentase $39 \%$ berusia $\geq 27$ tahun yaitu 141 orang. Karakteristik responden berdasarkan pekerjaan, diketahui total responden adalah 365 , pada karakteristik responden yang memiliki pekerjaan sebagai PNS mendapat prosentase sebesar 5,21\% yaitu berjumlah 19 orang. Lalu $14,52 \%$ memiliki pekerjaan sebagai pelajar/mahasiswa yaitu sebanyak 53 orang. Kemudian untuk pekerjaan pegawai swasta mendapat prosentase sebesar $42,74 \%$ yaitu sebanyak 156 orang. Untuk pekerjaan selain PNS, pelajar/mahasiswa dan pegawai swasta yaitu mendapat prosentase sebesar 
$37,53 \%$ yaitu 137 orang. Karakteristik responden berdasarkan lama berlangganan, diketahui total responden adalah 365, pada karakteristik responden yang berlangganan selama $1-12$ bulan mendapat prosentase sebesar $27,12 \%$ yaitu berjumlah 99 orang. Lalu 21,64\% berlangganan selama 13 - 25 bulan yaitu sebanyak 79 orang. Kemudian untuk berlangganan selama $26-32$ bulan mendapat prosentase sebesar $28,77 \%$ yaitu sebanyak 105 orang. Untuk berlangganan selama $>33$ bulan mendapat prosentase sebesar $22,47 \%$ yaitu 82 orang.

Uji Validitas

Uji validitas dilakukan pada kuisioner harapan dan persepsi pelanggan dengan $\mathrm{r}_{\text {tabel }}$ untuk degree of freedom $(\mathrm{df})=\mathrm{n}-2$, dan jumlah sampel adalah 365 dengan alfa 0,05 maka nilai $\mathrm{r}_{\text {tabelnya sebesar }}$ 0,1026 . Jika nilai $r$ hitung lebih besar dari nilai $r$ tabel $\left(r_{\text {hitung }}>r_{\text {tabel }}\right)$, maka pernyataan dikatakan valid.

Uji Reliabilitas

Untuk mengetahui hasil kuisioner dapat dihandalkan atau konsisten dari waktu ke waktu yaitu dengan menguji reliabilitas. Berdasarkan pengelompokkan reliabilitas maka hasil perhitungan reliabilitas pada kuisioner harapan mendapatkan Cronbach Alpha sebesar 0,505 artinya pada kuisioner harapan sudah cukup reliabel. Untuk kuisioner persepsi mendapatkan Cronbach Alpha sebesar 0,554 yang artinya pada kuisioner persepsi sudah cukup reliabel atau dapat dihandalkan.

Tingkat kepuasan pelanggan

Tingkat kepuasan pelanggan ditentukan pada nilai rata - rata persepsi pelanggan, untuk mengetahui tingkat kepuasan pelanggan yaitu dengan menggunakan nilai pada skala likert. Ini merupakan hasil dari penilaian kepuasan pelanggan.

Tabel 1. Tingkat Kepuasan Pelanggan

\begin{tabular}{ccc}
\hline Atribut & Rata - rata persepsi & Tingkat Kepuasan \\
\hline X4.3 & 4,334 & Puas \\
\hline X5.2 & 4,258 & Puas \\
\hline X4.4 & 4,252 & Puas \\
\hline X1.1 & 4,219 & Puas \\
\hline X3.3 & 4,168 & Puas \\
\hline X5.3 & 4,115 & Puas \\
\hline X2.1 & Puas \\
\hline X2.3 & 4,077 & Puas \\
\hline X3.1 & 4,074 & Puas \\
\hline X3.2 & 4,063 & Puas \\
\hline X4.2 & 4,060 & Puas \\
\hline X1.3 & 4,033 & Cukup puas \\
\hline X4.1 & 3,981 & Cukup puas \\
\hline X2.3 & 3,964 & Cukup puas \\
\hline X5.1 & 3,951 & Cukup puas \\
\hline & 3,945 & \\
\hline & & \\
\hline & & \\
\hline & & \\
\hline & & \\
\hline & & \\
\hline
\end{tabular}




\begin{tabular}{ccl}
\hline X2.4 & 3,852 & Cukup puas \\
\hline X1.4 & 3,803 & Cukup puas \\
\hline X3.4 & 3,751 & Cukup puas \\
\hline X1.2 & 3,638 & Cukup puas \\
\hline
\end{tabular}

Skor Servqual

Skor Servqual dapat diartikan sebagai nilai selisih antara nilai harapan dan nilai persepsi pelanggan. Jika nilai skor servqual/ gap positif maka persepsi pelanggan melebih harapan pelanggan. Sedangkan, apabila nilai servqual negatif maka nilai persepsi pelanggan masih belum memenuhi harapan pelanggan.

Tabel 2. Perhitungan Nilai Servqual

\begin{tabular}{ccccc}
\hline No. & Atribut & Rata-rata persepsi & Rata-rata harapan & Gap (servqual) \\
\hline 1 & X1.1 & 4,219 & 4,389 & $-0,170$ \\
\hline 2 & X1.2 & 3,638 & 3,630 & 0,008 \\
\hline 3 & X1.3 & 3,981 & 3,984 & $-0,003$ \\
\hline 4 & X1.4 & 3,803 & 3,762 & 0,041 \\
\hline 5 & X2.1 & 4,077 & 4,181 & $-0,104$ \\
\hline 6 & X2.2 & 4,074 & 4,118 & $-0,044$ \\
\hline 7 & X2.3 & 3,951 & 3,929 & 0,022 \\
\hline 8 & X2.4 & 3,852 & 3,885 & $-0,033$ \\
\hline 9 & X3.1 & 4,063 & 4,090 & $-0,027$ \\
\hline 10 & X3.2 & 4,060 & 4,173 & $-0,113$ \\
\hline 11 & X3.3 & 4,168 & 4,189 & $-0,021$ \\
\hline 12 & X3.4 & 3,751 & 3,745 & 0,006 \\
\hline 13 & X4.1 & 3,964 & 3,984 & $-0,020$ \\
\hline 14 & X4.2 & 4,033 & 4,030 & 0,003 \\
\hline 15 & X4.3 & 4,334 & 4,474 & $-0,140$ \\
\hline 16 & X4.4 & 4,252 & 4,323 & $-0,071$ \\
\hline 17 & X5.1 & 3,945 & 3,912 & 0,033 \\
\hline 18 & X5.2 & 4,258 & 4,310 & $-0,052$ \\
\hline 19 & X5.3 & 4,115 & 4,236 & $-0,121$ \\
\hline & Rata-rata & 4,025 & 4,071 & $-0,046$ \\
\hline
\end{tabular}

Berdasarkan pehitungan servqual diketahui terdapat 6 atribut yaitu X1.2, X1.4, X2.3, X3.4, X4.2 dan X5.1 memiliki nilai servqual positif artinya kualitas layanan pada atribut tersebut telah melampaui apa yang diharpkan pelanggan. Sedangkan terdapat 13 atribut memiliki nilai servqual negatif yaitu terdapat pada atribut X1.1, X1.3, X1.4, X2.1, X2.2, X2.4, X3.1, X3.2, X3.3, X3.4, $\mathrm{X} 4.4$, X5.2, dan X5.3 artinya atribut tersebut belum memenuhi harapan pelanggan.

Diagram Kartesius

Untuk menggambarkan nilai rata - rata harapan dan rata - rata persepsi pelanggan yaitu dengan menggunakan diagram kartesius. 


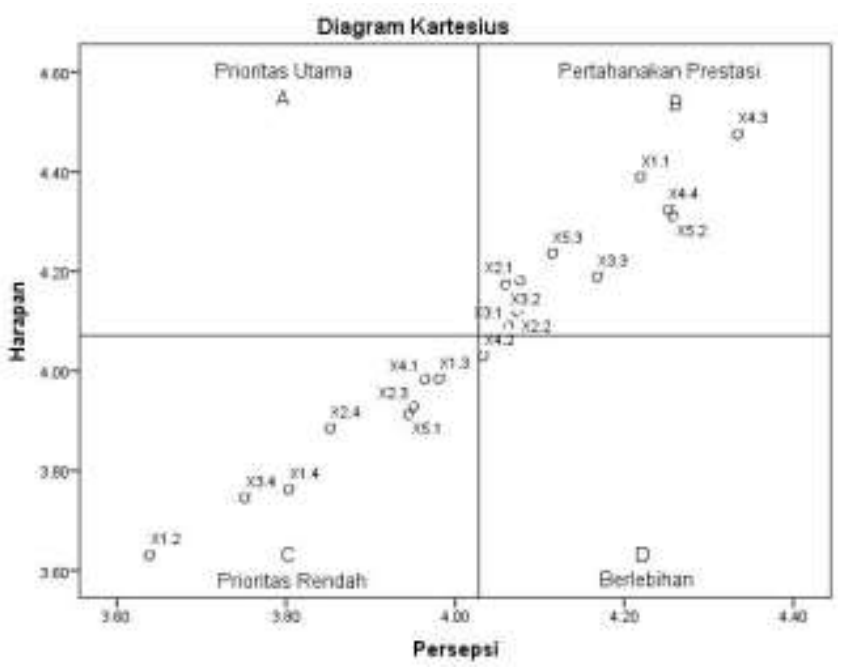

Gambar 1. Diagram Kartesius

Berdasarkan gambar diatas diketahui bahwa atribut X2.1, X3.2, X3.1, X2.2, X5.3, X3.3, X5.2, X4.4, X1.1 dan X4.3 berada pada kelompok Pertahankan Prioritas artinya pada layanan tersebut mempunyai tingkat harapan dan persepsi yang tinggi maka pada kelompok ini perusahaan hanya harus mempertahankan kualitas layanan pada atribut tersebut. Kemudian untuk atribut X1.2, X3.4, X1.4, X2.4, X2.3, X5.1, X4.1 dan X1.3 berada pada kelompok Prioritas Rendah artinya layanan tersebut memiliki rata - rata tingkat harapan yang rendah dan juga rata rata persepsi yang rendah maka pada kelompok ini perusahaan perlu sedikit meningkatkan kualitas layanan pada atribut tersebut. Sedangkan untuk atribut X4.2 berada pada kelompok Berlebihan artinya memiliki layanan dengan tingkat harapan rendah bagi pelanggan, namun kinerja layanan tersebut tinggi maka perusahaan perlu menurunkan kinerja pada atribut tersebut.

Pembobotan dengan Metode AHP

Pada metode AHP dilakukan untuk menyusun prioritas perbaikan pada layanan X. Pembobotan dilakukan pada kriteria dan sub kriteria dimana kriteria merupakan 5 dimensi servqual dan sub kriteria merupakan 19 atribut pernyataan.

Perhitungan nilai servqual terbobot

Nilai servqual merupakan nilai kesenjangan atau gap yang diperoleh dari selisih antara nilai harapan dan nilai persepsi pelanggan terhadap kualitas layanan. Untuk menghasilkan nilai servqual terbobot yaitu mengkalikan nilai servqual dengan nilai bobot global. Hasil perhitungan nilai servqual terbobot terdapat pada tabel berikut.

Tabel 3. Pehitungan Nilai Servqual Terbobot

\begin{tabular}{|c|c|c|c|c|c|c|}
\hline No. & Atribut & $\begin{array}{c}\text { Bobot } \\
\text { kriteria }\end{array}$ & $\begin{array}{l}\text { Bobot sub } \\
\text { kriteria }\end{array}$ & $\begin{array}{l}\text { Bobot } \\
\text { Global }\end{array}$ & $\begin{array}{c}\text { Nilai (Gap) } \\
\text { Servqual }\end{array}$ & $\begin{array}{c}\text { Nilai } \\
\text { Servqual } \\
\text { Terbobot }\end{array}$ \\
\hline 1 & $\mathrm{X} 1.1$ & \multirow{4}{*}{0,304} & 0,444 & 0.198 & $-0,170$ & -0.0336 \\
\hline 2 & X1.2 & & 0,236 & 0.105 & 0,008 & 0.0008 \\
\hline 3 & X1.3 & & 0,160 & 0.071 & $-0,003$ & -0.0002 \\
\hline 4 & X1.4 & & 0,160 & 0.071 & 0,041 & 0.0029 \\
\hline 5 & X2.1 & \multirow{5}{*}{0,218} & 0,548 & 0.301 & $-0,104$ & -0.0313 \\
\hline 6 & $\mathrm{X} 2.2$ & & 0,168 & 0.092 & $-0,044$ & -0.0041 \\
\hline 7 & $\mathrm{X} 2.3$ & & 0,148 & 0.081 & 0,022 & 0.0018 \\
\hline 8 & X2.4 & & 0,136 & 0.074 & $-0,033$ & -0.0025 \\
\hline 9 & X3.1 & & 0,548 & 0.301 & $-0,027$ & -0.0081 \\
\hline
\end{tabular}




\begin{tabular}{|c|c|c|c|c|c|c|}
\hline 10 & X3.2 & \multirow{3}{*}{0,151} & 0,178 & 0.098 & $-0,113$ & -0.0110 \\
\hline 11 & X3.3 & & 0,160 & 0.088 & $-0,021$ & -0.0018 \\
\hline 12 & X3.4 & & 0,114 & 0.062 & 0,006 & 0.0004 \\
\hline 13 & $\mathrm{X} 4.1$ & \multirow{4}{*}{0,205} & 0,321 & 0.103 & $-0,020$ & -0.0021 \\
\hline 14 & $\mathrm{X} 4.2$ & & 0,342 & 0.110 & 0,003 & 0.0003 \\
\hline 15 & $\mathrm{X} 4.3$ & & 0,258 & 0.083 & $-0,140$ & -0.0116 \\
\hline 16 & $\mathrm{X} 4.4$ & & 0,079 & 0.025 & $-0,071$ & -0.0018 \\
\hline 17 & X5.1 & \multirow{3}{*}{0,123} & 0,665 & 0.442 & 0,033 & 0.0146 \\
\hline 18 & X5.2 & & 0,231 & 0.154 & $-0,052$ & -0.0080 \\
\hline 19 & X5.3 & & 0,104 & 0.069 & $-0,121$ & -0.0084 \\
\hline \multicolumn{6}{|c|}{ RATA - RATA } & $-0,0054$ \\
\hline
\end{tabular}

Berdasarkan hasil perhitungan servqual terbobot diatas terdapat 7 atribut yang memiliki nilai servqual terbobot lebih rendah dari nilai rata - rata servqual terbobot. Atribut tersebut diantaranya X1.1 (Kerapian dalam instalasi perkabelan), X2.1 (paket/layanan X jarang mengalami gangguan), X4.3 (Karyawan siap memberikan layanan apabila terjadi gangguan kembali), X3.2 (Karyawan cepat dalam memberikan penjelasan dan kepastian perbaikan terhadap gangguan), X5.3 (PT. XYZ memberikan perhatian kepada setiap pelanggan), X3.1 (karyawan produk X memberikan pelayanan yang cepat terhadap gangguan) dan X5.2 (karyawan produk X melayani setiap keluhan pelanggan dengan penuh perhatian).

\section{PENUTUP}

Kesimpulan pada penelitian ini (1) Servqual dan AHP merupakan metode yang baik digunakan untuk menentukan kepuasan pelanggan, meningkatkan kualitas layanan dan menyusun prioritas perbaikan kualitas layanan. Tingkat kepuasan pelanggan di PT. XYZ dimata pelanggan diketahui dari nilai persepsi pelanggan mencapai angka 4,025 artinya pelanggan sudah puas dengan pelayanan saat ini. Namun, dari hasil perhitungan servqual masih terdapat kesenjangan sebesar - 0,046. (2) Urutan atribut yang memerlukan perbaikan kualitas layanan yaitu dapat dilihat berdasarkan hasil perhitungan nilai servqual terbobot dimana terdapat 7 nilai servqual terbobot yang memiliki nilai lebih kecil dari nilai rata - rata servqual terbobot yaitu -0,0054. Atribut tersebut yaitu X1.1, X2.1, X4.3, X3.2, X5.3, X3.1 dan X5.3.

Saran bagi perusahaan (1) Dapat menggunakan urutan usulan perbaikan terhadap atribut layanan pada penelitian ini dalam melakukan perbaikan kualitas layanan X (2) Bagi peneliti selanjutnya yaitu dapat melakukan penelitian kepuasan pelanggan terhadap kualitas layanan dengan jasa yang serupa yang berbeda agar diketahui kondisi pada perusahaan pesaing.

\section{DAFTAR PUSTAKA}

Ambara, \& Desti, N. W. (2015). Penilaian Service Quality Plasa Telkom Lembong Bandung. $e$ Proceeding of Management: Vol.2, No.3.

Andary, M. A. (2018). Analisi Kepuasan Pelanggan Terhadap Pelayanan Jasa Transportasi Massal Dengan Menggunakan Metode Servqual Pada PT. Mayasari Bakti. Jurnal Teknokris vol. 21, No. 1 .

Ahsan. M, Santoso. PB, Dachlan. HS. (2018). Multiple Intelligence Menentukan Jurusan di SMA Menggunakan Teknik Multi-Attribute Decision Making. Jurnal EECCIS 9 (1), pp. 25 30 .

Ahsan. M, Setiyaningsih. W, Susilowati. M, Dijaya. R, Tjahjanti. PH. (2019). Selecting multiple intelligences on children with weighted product, analytical hierarchy process, simple additive weighting and TOPSIS. Journal of Physics: Conference Series 1402 (7), 077033. 
Dewi Astuti, F., Dewi, A., \& Feby, S. N. (2016). Analisis Kualitas Layanan E-Commerce Terhadap Kepuasan Pelanggan Menggunakan Metode E-Servqual (Studi Kasus: Lejel Home Shopping PekanBaru). Jurnal Rekayasa dan Manajemen Sistem Informasi, Vol. 2, No. 1.

Fandy, \& Tjiptono. (2005). Service Marketing: Esensi \& Aplikasi. Yogyakarta: Marknesis.

Freddy, R. (2006). Riset Pemasaran. Jakarta: Gramedia Pustaka Utama.

Freddy, R. (2006). Teknik Mengukur dan Strategi Meningkatkan Kepuasan Pelanggan . Jakarta: PT. Gramedia Pustaka Utama .

Hendy , T., Bilyy, A., Filscha, N., \& Mirna, L. (2017). Analisi Kualitas Jasa Pada Maskapai Penerbangan Rute Domestik Tarif Menengah Kebawah dengan Menggunakan Metode Servqual dan Metode Importance And Performance Analysis. Prosiding SNATIF Ke-4.

Heru, W., \& Tb. Absor. (2018). Analisis Kualitas Pelayanan Dengan Metode Service Quality (Servqual) dan Importance Performance Analysis (IPA) Pada PT. Media Purna Engineering. Jurnal Manajemen Industri Dan Logistik Vol. 1 No.2.

Imam, G. (2012). Aplikasi Analisis Multivariate dengan Program IBM SPSS. Yogyakarta: Universitas Diponegoro.

Ladyana, S. S. (2016). Penilaian Kualitas Pelayanan Digital Lounge Menggunakan Metode Servqual dan Analytical Hierarchy Process. Bina Insani Ict Journal, Vol. 3, No.1.

Lapita, S. S., Jijon, S. R., \& Asaziduhu, G. (2018). Implementasi Sistem Pendukung Keputusan Dengan Metode AHP Dalam Menentukan Tingkat Kepuasan Pelanggan. Jurnal Armada Informatika Vol 2, No. 1.

Lissa, N. R. (2016). Analisis Peningkatan Kualitas Pelayanan Mahasiswa Magister Manajemen Teknologi ITS Surabaya Dengan Metode Servqual dan Imprtance Performance Analysis (IPA). Journal of Research and Technologies, Vol. 2 No. 1.

Michelle , H., Lucy , S., Jessica , P., \& Agnes, K. Y. (2017). Analisis Kepuasan Konsumen terhadap Pelayanan Restoran Cepat Saji (Restoran X) dengan Metode Service Quality (Servqual). Jurnal Metris. Vol 18. No. 2.

Sugiyono. (2010). Statistika Untuk Penelitian. Bandung: Alfabeta.

Supranto. (2006). Mengukur Tingkat Kepuasan Pelanggan atau Konsumen . Jakarta: Rineke Cipta.

Tjiptono. (2011). Kepuasan Pelanggan Dalam Manajemen Kualitas Jasa hal. 152. Jakarta: PT. Indeks.

Wijaya, \& Tony. (2011). Manajemen Kualitas Jasa: Desain Servqual. QFD, dan Kano. Jakarta: PT Indeks.

Yandra, P., Dyah, L. R., \& M. Shodiq, K. A. (2019). Penerapan Metode Service Quality (Servqual) Untuk Peningkatan Kualitas Pelayanan Pelanggan. Jurnal OPSI Vol 12 No.1. 